\title{
ANALISIS DETERMINAN FAKTOR STRUKTUR MODAL DI BURSA EFEK INDONESIA TAHUN 2016-2019
}

\author{
Carissa Dessy Rianti, Marsheila Eka Dianti, Sandra Zaeni
}

Fakultas Ekonomi dan Bisnis Universitas Budi Luhur, Jakarta, Indonesia

Email: carissarianti@gmail.com,marsheilaekadianti@gmail.com, sandra.zaenijen@gmail.com

INFO ARTIKEL
Diterima
Direvisi
15 Desember 2021
Disetujui
21 Januari 2022

\section{Kata Kunci:}

industri kelapa sawit;

profitabilitas; struktur asset; pertumbuhan perusahaan; ukuran perusahaan; struktur modal; regresi berganda.
Keywords:

Palm oil industry; profitability; structure of assets; company growth; size of company; capital structure; multiple linier regression

\section{ABSTRAK}

Tujuan penelitian ini untuk menganalisis pengaruh profitabilitas, struktur aset, pertumbuhan perusahaan, ukuran perusahaan terhadap struktur modal. Untuk maksud tujuan tersebut objek penelitian dilakukan pada perusahaan perkebunan kelapa sawit yang terdaftar di Bursa Efek Indonesia periode 2016-2019. Berdasarkan kriteria sampel yang ada diperoleh 11 perusahaan yang memenuhi kriteria yaitu perusahaan tersebut menyajikan laporan keuangan lengkap periode penelitian. Alat pengukuran penelitian yang digunakan adalah analisis regresi linier berganda karena mempunyai kemampuan dapat memprediksi pengaruh variabel bebas terhadap variabel terikat. Hasil penelitian diperoleh kesimpulan bahwa variabel profitabilitas, struktur aset dan pertumbuhan perusahaan memiliki pengaruh dan signifikan terhadap struktur modal sedangkan variabel ukuran perusahaan tidak memiliki pengaruh terhadap struktur modal. Secara simultan keempat variable tersebut mempunyai pengaruh yang kuat mencapai 60,6\% terhadap struktur modal. Metode yang digunakan dalam penelitian ini adalah metode analisis regresi linier berganda yaitu penelitian dilakukan untuk mengetahui pengaruh satu atau lebih variabel terhadap variabel tertentu yang merupakan sebab akibat.

ABSTRACT
The purpose of this study is to analyze the influence of profitability,
asset structure, company growth, company size on capital structure.
For this purpose, the research object was conducted at oil palm
plantation companies listed on the Indonesia Stock Exchange for the
period 2016-2019. Based on the existing sample criteria obtained by
11 companies that meet the criteria, the company presents the
complete financial statements of the research period. The research
measurement tool used is multiple linear regression analysis because it
has the ability to predict the influence of free variables on bound
variables. The results of the study concluded that the variables of
profitability, asset structure and growth of the company have an
influence and significant on the structure of capital while the size
variables of the company have no influence on the structure of capital.
Simultaneously the four variables have a strong influence of $60.6 \%$ on
the capital structure. The method used in this study is a method of
multiple linear regression analysis that is research conducted to
determine the influence of one or more variables on certain variables
that are causation.

\section{ABSTRACT}

The purpose of this study is to analyze the influence of profitability, asset structure, company growth, company size on capital structure. For this purpose, the research object was conducted at oil palm plantation companies listed on the Indonesia Stock Exchange for the period 2016-2019. Based on the existing sample criteria obtained by 11 companies that meet the criteria, the company presents the complete financial statements of the research period. The research measurement tool used is multiple linear regression analysis because it has the ability to predict the influence of free variables on bound profitability, asset structure and growth of the company have an influence and significant on the structure of capital while the size variables of the company have no influence on the structure of capital. Simultaneously the four variables have a strong influence of $60.6 \%$ on the capital structure. The method used in this study is a method of that are causation.

$\begin{array}{ll}\text { How to cite: } & \text { Rianti, C. D., Marsheila Eka Dianti, Sandra Zaeni (2022). Analisis Determinan Faktor Struktur } \\ & \text { Modal Di Bursa Efek Indonesia Tahun 2016-2019, Jurnal Syntax Transformation, 3(1). } \\ & \text { https://doi.org/10.46799/jst.v3i1.491 } \\ \text { E-ISSN: } & 2721-2769 \\ \text { Published by: } & \text { Ridwan Institute }\end{array}$




\section{Pendahuluan}

Teori struktur modal bertujuan memberikan landasan berfikir untuk mengetahui struktur modal yang optimal. Struktur modal dikatakan optimal apabila dengan tingkat risiko tertentu dapat memberikan nilai perusahaan yang maksimal. Tujuan utama perusahaan adalah meningkatkan nilai perusahaan melalui peningkatan kemakmuran pemilik atau pemegang saham (Brigham \& Houston, 2006). Nilai perusahaan adalah harga yang bersedia dibayar oleh calon pembeli apabila perusahaan tersebut dijual. Bagi perusahaan yang menerbitkan saham di pasar modal, harga saham yang diperjualbelikan di bursa merupakan indikator nilai perusahaan (Husnan, 2004).

Penentuan struktur modal merupakan kebijakan yang diambil oleh manajemen dalam rangka memperoleh sumber dana sehingga sehingga dapat dipergunakan untuk aktifitas operasional perusahaan. Keputusan yang diambil oleh manajemen dalam pencarian sumber dana tersebut sangat dipengaruhi oleh para pemilik atau pemegang saham. Sesuai dengan tujuan utama perusahaan adalah eningkatkan kemakmuran pemegang saham, maka setiap kebijakan yang akan diambil manajemen selalu dipengaruhi oleh keinginan pemegang sahamnya (Brigham \& Houston, 2010).

Menurut (Ang, 1997), setelah struktur modal ditentukan, maka perusahaan selanjutnya akan menggunakan dana yang diperoleh tersebut untuk operasional perusahaan. Aktifitas operasional perusahaan dikatakan menguntungkan jika return yang diperoleh dari hasil operasional tersebut lebih besar daripada biaya modal (cost of capital).

Cost of capital adalah merupakan ratarata tertimbang dari biaya modal (cost of fund) yang terdiri dari bunga pinjaman dan biaya modal sendiri (Tbk \& Tbk, 2013). Biaya modal sendiri terdiri dari dividen yang dibayarkan kepada pemegang saham biasa dan preferen. Biaya bunga pinjaman merupakan biaya bunga bersih setelah dikurangi pajak. Besarnya komposisi dari hutang dan modal sendiri serta biaya yang ditimbulkan itulah yang perlu dipertimbangkan oleh manajemen apakah akan memperbesar rasio hutang ataukah sebaliknya yaitu memperkecil rasio hutang.

Untuk mengetahui faktor yang mempengaruhi struktur modal perusahaan maka dapat dikatakan harus dapat mengetahui terlebih dahulu faktor yang mempengaruhi pinjaman hutang. Seperti yang dijelaskan (RINI, 2014) bahwa perusahaan dengan profitabilitas tinggi dan penggunan internal financing yang lebih besar dapat menurunkan penggunaan hutang (rasio hutang).

Perusahaan dengan tingkat pengembalian yang tinggi atas investasi menggunakan hutang yang relatif kecil. Tingkat pengembalian yang tinggi memungkinkan untuk membiayai sebagian besar kebutuhan pendanaan dengan dana yang dihasilkan secara internal (Weston \& Brigham, 2001).

Menurut (Cahyono, 2017) menyatakan bahwa perusahaan yang lebih besar yang sahamnya tersebar sangat luas akan lebih berani mengeluarkan saham baru dalam memenuhi kebutuhannya untuk membiayai pertumbuhan penjualannya dibandingkan perusahaan yang lebih kecil. Sehingga semakin besar ukuran perusahaan, kecenderungan untuk memakai dana eksternal juga semakin besar. Hal tersebut dikarenakan perusahaan besar memiliki kebutuhan dana yang besar dan salah satu alternatif pemenuhan dana adalah dengan menggunakan dana eksternal yaitu dengan menggunakan hutang. Sehingga semakin besar ukuran perusahaan kecenderungan untuk menggunakan hutang lebih besar untuk memenuhi kebutuhan dananya dari pada perusahaan kecil.

Perusahaan dengan penjualan yang relatif stabil akan lebih mudah memperoleh 
pinjaman, maka semakin stabil perusahaan menyebabkan semakin besar kemungkinan perusahaan membelanjakan kegiatan dengan hutang. Dengan kata lain, pertumbuhan penjualan memiliki pengaruh positif terhadap struktur modal. Struktur modal sendiri tidak terlepas dari berbagai faktor antara lain pembayaran dividen.

Industri perkebunan kelapa sawit diyakini merupakan salah satu industri yang mampu mengentaskan kemiskinan di Indonesia (Pahan, 2008). Hal ini disebabkan industri kelapa sawit merupakan sumber daya alam yang dapat diperbaharui berupa lahan yang subur, tenaga kerja yang produktif dan sinar matahari yang melimpah sepanjang tahun.

Kelapa sawit merupakan tanaman paling produktif dengan produksi minyak per hektar yang paling tinggi dari seluruh tanaman penghasil minyak nabati lainnya. Selain itu juga industri kelapa sawit salah satu dari sedikit industri yang memiliki keunggulan kompetitif Indonesia untuk bersaing di pasar global. Sistem agribisnis dapat dikelompokkan ke dalam empat subsistem kegiatan sesuai gambar di bawah (Pahan, 2012).

Menurut Uma Sekaran 2007 dalam (Febrioni et al., 2016) , mengungkapkan hipotesis sebagai hubungan yang diperkirakan secara logis diantara dua atau lebih variabel yang diungkapkan dalam bentuk pernyataan yang dapat diuji. Hubungan tersebut diperkirakan berdasarkan jaringan asosiasi yang ditetapkan dalam kerangka teoritis yang dirumuskan untuk studi penelitian. Dengan menguji hipotesis dan menegaskan perkiraan hubungan, diharapkan bahwa solusi dapat ditemukan untuk mengatasi masalah yang dihadapi.

Dari berbagai penelitian yang telah dilakukan sebelumnya dan berdasarkan kerangka pemikiran yang telah diuraikan, maka hipotesis dalam penelitian ini adalah sebagai berikut:
H0: Profitabilitas tidak berpengaruh terhadap struktur modal.

H1: Profitabilitas berpengaruh terhadap struktur modal.

H0: Struktur aset tidak berpengaruh terhadap struktur modal.

H2: Struktur aset berpengaruh terhadap struktur modal.

H0: Pertumbuhan perusahaan tidak berpengaruh terhadap struktur modal.

H3: Pertumbuhan perusahaan berpengaruh terhadap struktur modal.

H0: Ukuran perusahaan tidak berpengaruh terhadap struktur modal.

H4: Ukuran perusahaan berpengaruh terhadap struktur modal.

Pengaruh simultan keempat variabel bebas terhadap struktur modal

H0: Profitabilitas, struktur asset, pertumbuhan perusahaan dan ukuran perusahaan semuanya tidak berpengaruh terhadap struktur modal.

H5: Profitabilitas, struktur asset, pertumbuhan perusahaan dan ukuran perusahaan semuanya berpengaruh terhadap struktur modal.

\section{Metode Penelitian}

Metode yang digunakan dalam penelitian ini adalah metode analisis regresi linier berganda yaitu penelitian dilakukan untuk mengetahui pengaruh satu atau lebih variabel terhadap variabel tertentu yang merupakan sebab akibat (Janie, 2012).

Penelitian ini menggunakan data sekunder melalui data yang diambil dari BEI dengan periode laporan keuangan 2016-2019 dan melalui buku perpustakaan yang berkaitan dengan variabel yang ada.

Skala pengukuran yang digunakan adalah skala rasio. Penelitian ini menggunakan Statistical Package For the Social Science (SPSS) versi 22.0 sebagai alat olah data statistik untuk mengetahui tingkat signifikasi dan pengaruh variabel dalam penelitian ini. 
Populasi dalam penelitian ini adalah perusahaan perkebunan kelapa sawit yang terdaftar di BEI periode 2016-2019. Metode pemilihan sampel pada penelitian ini adalah purposive sampling dimana peneliti memilih sampel berdasarkan karakteristik anggota sampel yang disesuaikan dengan maksud penelitian Kriteria pemilihan sampel adalah sebagai berikut :

Perusahaan perkebunan kelapa sawit yang terdaftar di Bursa Efek Indonesia (BEI).

Perusahaan masih terdaftar di BEI pada periode pengamatan (2016-2019).

Perusahaan sektor agriculture yang bergerak di bidang budidaya kelapa sawit tidak termasuk industri hilir (pengolahan CPO sebagai bahan dasar).

Periode laporan keuangan lengkap yang berakhir 31 Desember dan dipublikasikan berturut-turut selama tahun pengamatan. Dari kriteria tersebut penulis mengambil sampel sebanyak 16 perusahaan perkebunan kelapa sawit yang terdaftar di BEI. Metode penarikan sampel dalam penelitian ini menggunakan metode purposive random sampling yaitu sampel yang dipilih dengan cermat hingga relevan dengan kriteria tertentu.

\section{Hasil dan Pembahasan}

Pada bagian ini akan diuraikan mengenai statistik deskriptif yang menguraikan mengenai nilai minimum merupakan nilai terendah untuk setiap variabel. sedangkan nilai maksimum merupakan nilai tertinggi untuk setiap variabel dalam penelitian. Nilai mean merupakan nilai rata-rata dari setiap variabel yang diteliti. Standar deviasi merupakan sebaran data yang digunakan dalam penelitian yang mencerminkan data itu heterogen atau homogen yang sifatnya fluktuatif. Berikut ini adalah pengujian statistik deskriptif untuk variabel dependen dan variabel independennya

\section{A. Hasil Penelitian}

Tabel 1

Hasil Uji Statistik Deskriptif

\begin{tabular}{ccccccc}
\hline & Struktur modal & Profitabilitas & Struktur asset & Growth & Size \\
\hline $\mathrm{N}$ & 55 & 55 & 55 & 55 & 55 \\
\cline { 2 - 7 } & Valid & - & - & - & - & - \\
\hline Missing & 0.473 & 0.086 & 0.783 & 0.201 & 29.467 \\
\hline Mean & 0.513 & 0.072 & 0.809 & 0.191 & 29.456 \\
\hline Median & 0.178 & 0.103 & 0.135 & 0.279 & 1.006 \\
\hline Std. Deviation & 0.140 & 0.169 & 0.459 & 0.431 & 26.846 \\
\hline Minimum & 0.762 & 0.337 & 0.971 & 1.266 & 31.065 \\
\hline Maximum & & & & &
\end{tabular}

Berdasarkan Tabel diatas diketahui bahwa terdapat 5 variabel yang diteliti dengan jumlah sampel 11 perusahaan indistri perkebunan kelapa sawit yang sudah listed di BEI dengan $\mathrm{N}=55$.

Tabel tersebut menunjukkan bahwa untuk variabel struktur modal mempunyai nilai minimum sebesar 0,14 dan nilai maksimum 0,76 yang berarti bahwa nilai rasio struktur modal berada pada range tersebut. Dengan nilai mean 0,47 berarti bahwa nilai rata-rata berada pada kisaran angka 53,56\% dari range dan masih berada di atas nilai median 0,51 . Dengan standar deviasi 0,17 berarti bahwa perusahaan yang diteliti memiliki nilai rasio EBIT dibagi pembayaran bunga masih dalam kisaran di atas rata-rata dengan perbedaan deviasi yang kecil. 
Rata-rata variabel profitabilitas berada pada kisaran 50,29\% dari range 0,16 (nilai minimum) sampai dengan 0,33 (nilai maksimum) dan nilai ini di atas nilai tengah 0,071 . Mengacu kepada penghitungan rasio profitabilitas diketahui bahwa nilai profitabilitas perusahaan pada range yang tinggi (banyak perusahaan profit). Dengan standar deviasi 0,10 menunjukkan bahwa data profitabilitas yag digunakan tidak memiliki variasi yang tinggi atau homogen.

Untuk variabel struktur aset, standar deviasi 0,13 menujukkan bahwa bahwa data yang digunakan tidak memiliki data yang homogen pada kedudukan bahwa nilai aktiva tetap (fixed asset) terhadap total aset cukup tinggi yang berada pada rata-rata 0,782 . Nilai rata-rata ini berada pada kisaran range $63,20 \%$ yang berada masih di bawah nilai tengah 0,809 .

Nilai pertumbuhan perusahaan (growth) yang berada pada nilai rata-rata 0,201 yang berada di kisaran range 37,24\% dari nilai minimum ke maksimum dan berada di atas nilai tengah (median) 0,191. Dengan formula penghitungan rasio growth dapat dilihat bahwa perusahaan yang diteliti cukup berfluktuatif antara pertumbuhan yang tinggi dengan yang rendah.

Untuk variabel ukuran perusahaan (size) berada pada range minimum dan maksimun pada angka $62,10 \%$ dengan nilai mean 29.46. dalam penelitian ini variabel ukuran perusahaan yang diukur memiliki standar deviasi cukup tinggi pada nilai 1.005 yang berarti bahwa perusahaan yang diteliti bercampur antara perusahaan yang besar, sedang dan kecil (heterogen ukurannya).

1. Uji Asumsi Klasik

Uji asumsi klasik bertujuan agar mendapatkan model penelitian yang valid dan dapat digunakan dalam estimasi. Pada pengujian asumsi ini terdiri dari uji normalitas, uji multikolinearitas, uji heteroskedatisitas dan uji auto korelasi dengan menggunakan program SPSS versi 22.0 untuk pengolahan data statistik. a. Uji Normalitas

Dari hasil pengujian Kolmogorov-Smirnov test pada Tabel diatas, dapat dilihat melalui pengujian distribusi normal dengan menggunakan alat uji One Sample Kolmogorov-Smirnov Test terlihat bahwa nilai signifikansi $0,20>0,05$ yang berarti data yang diuji terdistribusi secara normal dan layak dipakai dalam pengujian ini.

Tabel 2

Hasil Uji Kolmogorov Smirnov

\begin{tabular}{lcc}
\hline & & Unstandardized Residual \\
\hline $\mathrm{N}$ & & 53 \\
\hline Normal parameter ${ }^{\mathrm{a}, \mathrm{b}}$ & Mean & 0 \\
\cline { 2 - 3 } & Std. Deviation & 0.107536 \\
\cline { 2 - 3 } & Absolute & 0.087 \\
\hline \multirow{2}{*}{ Most Extreme Differences } & Positive & 0.062 \\
\cline { 2 - 3 } & Negative & 0.087 \\
\hline Test statistic & & 0.087 \\
\hline Asymp. Sig. (2-tailed) & & $.200^{\mathrm{c}, \mathrm{d}}$ \\
\hline
\end{tabular}

a. Test distribution is normal

b. Calculated from data

c. Liliefors significance correction

d. This is a lower bound of the true significance 
b. Uji Multikolinearitas

Dari hasil pengolahan data statistik diperoleh tabel pengujian multikolinearitas sebagai berikut :

Tabel 3

Tabel Hasil Uji Multikolinearitas

\begin{tabular}{cccc}
\hline & Model & \multicolumn{2}{c}{ Collinearity statistic } \\
\cline { 2 - 4 } & & Tolerance & VIP \\
\hline 1 & Constant & & \\
\cline { 2 - 4 } & Profitabilitas & 0.885 & 1.13 \\
\cline { 2 - 4 } & Struktur asset & 0.846 & 1.183 \\
\hline Gwoth & 0.984 & 1.016 \\
\hline Size & 0.917 & 1.091 \\
\hline
\end{tabular}

Dari tabel hasil uji multikolinearitas di atas diketahui bahwa seluruh variabel independen yakni profitabilitas, struktur aset, pertumbuhan perusahaan dan ukuran perusahaan memiliki Variance Inflation Factor (VIF) <10. Hal ini berarti dapat disimpulkan bahwa model regresi yang digunakan terhindar dari masalah multikolinearitas atau dengan kata lain tidak ada multikolinearitas sehingga

model yang digunakan dalam penelitian dapat diteruskan.

c. Uji Autokorelasi

Pengujian statistik atas data diketahui nilai uji autokorelasi seperti pada tabel berikut ini. Dari tabel Durbin-Watson atas nilai dL dan dU pada Sig. 0.05 , dengan $n=53$ dan $k=4$ variabel independen maka diketahui nilai $\mathrm{dL}=1.40$ dan $\mathrm{dU}=1.72$.

Tabel 4

Hasil Uji Autokorelasi

Model Summary ${ }^{\mathrm{b}}$

\begin{tabular}{cccccc}
\hline Model & $\mathbf{R}$ & $\begin{array}{c}\mathbf{R} \\
\text { Square }\end{array}$ & $\begin{array}{c}\text { Adjusted } \\
\text { R } \\
\text { Square }\end{array}$ & $\begin{array}{c}\text { Std. error } \\
\text { of } \\
\text { Estimate }\end{array}$ & $\begin{array}{c}\text { Durbin- } \\
\text { watson }\end{array}$ \\
\hline 1 & .798 & 0.637 & 0.608 & 0.11192244 & 1.888 \\
\hline
\end{tabular}

a. Predictors : (constant), size, growth, profitabilitas, struktur asset

b. Dependent variable : struktur modal

Berdasarkan hasil regresi diketahui nilai $\mathrm{DW}=1.88$ terletak di antara $\mathrm{dU}<\mathrm{dw}<4-\mathrm{dU}$ sehingga model regresi yang digunakan berada pada keputusan adanya autokorelasi dalam model regresi.

d. Uji Heteroskedastisitas

Analisis uji heteroskedasitisitas menggunakan grafik scatterplot menunjukkan bahwa titik-titik menyebar dan tidak membentuk pola tertentu yang jelas. Berdasarkan hal ini dapat disimpulkan bahwa tidak terjadi masalah heteroskedastisitas seperti terlihat di grafik berikut 


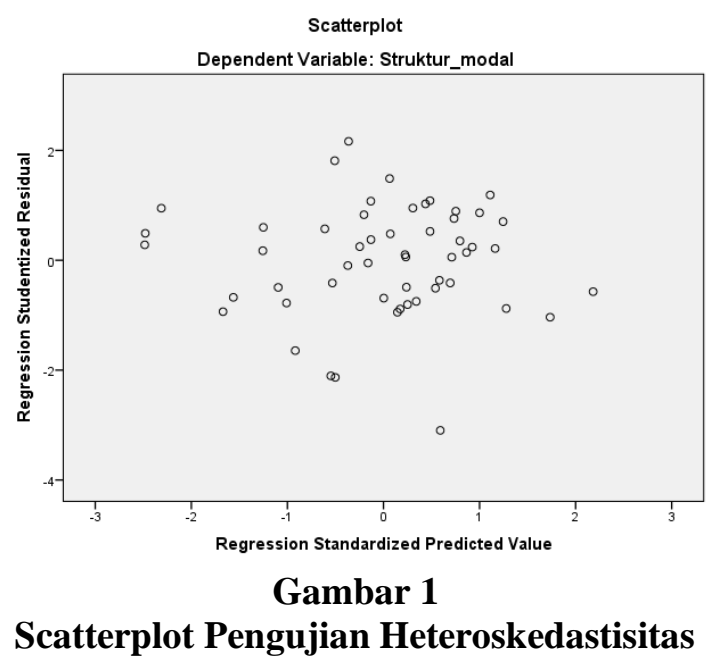

Dari gambar 1 terlihat bahwa semua nilai signifikansi lebih besar dari 0,05 berturut-turut 0,$802 ; 0,811$; 0,$579 ; \quad 0,355$ untuk variabel profitabilitas; struktur aset; growth; size sehingga disimpulkan bahwa keempat variabel bebas tersebut tidak terjadi masalah heteroskedastisitas.

Table 5

Tabel Hasil Pengujian Glejser Coefficients $^{\mathbf{a}}$

\begin{tabular}{cccccc}
\hline Model & \multicolumn{2}{c}{$\begin{array}{c}\text { Unstandardized } \\
\text { coefficient }\end{array}$} & $\begin{array}{c}\text { Standardized } \\
\text { coefficient }\end{array}$ & t & Sig \\
\cline { 2 - 5 } & $\mathrm{B}$ & $\begin{array}{c}\text { Std. } \\
\text { Error }\end{array}$ & Beta & & \\
\hline Constant & 0.366 & 0.335 & & 1.091 & 0.281 \\
\hline Profitabilitas & 0.025 & 0.098 & 0.038 & 0.253 & 0.802 \\
\hline $\begin{array}{c}\text { Struktur } \\
\text { Aset }\end{array}$ & 0.018 & 0.076 & 0.037 & 0.241 & 0.811 \\
\hline Growth & -0.022 & 0.04 & -0.08 & 0.558 & 0.579 \\
\hline Size & -0.01 & 0.011 & -0.139 & 0.934 & 0.355 \\
\hline
\end{tabular}

a. Dependent Variabel : RES2

e. Uji Hipotesis

1) Uji t Test Parsial

Uji independen sampel $t$ test digunakan untuk mengetahui apakah variabel bebas $(\mathrm{X})$ secara parsial (sendiri) berpengaruh terhadap variabel (Y) baik itu secara signifikan atau tidak. Berdasarkan nilai signifikansi hasil output SPSS:

a) Jika nilai Sig. $<0,05$ maka variabel bebas berpengaruh signifikan terhadap variabel terikat.

b) Jika nilai Sig. > 0,05 maka variabel bebas tidak berpengaruh signifikan terhadap variabel terikat.

Dasar pengambilan keputusan untuk uji t yaitu:

a) $\mathrm{H} 0$ diterima dan $\mathrm{H} 1$ ditolak jika nilai $\mathrm{t}$ hitung $<\mathrm{t}$ tabel atau jika nilai Sig. $>$ 0,05 .

b) $\mathrm{H} 0$ ditolak dan $\mathrm{H} 1$ diterima jika nilai $\mathrm{t}$ hitung $>\mathrm{t}$ tabel atau nilai Sig. $<0,05$. 
c) Berikut ini hasil output SPSS 22 untuk pengujian $t$ test parsial atas struktur modal sebagai variabel terikat dengan empat variabel bebas lainnya yaitu profitabilitas, struktur aset, pertumbuhan perusahaan dan ukuran perusahaan sebagai variabel bebasnya.

Tabel 6

Hasil Pengujian Parsial t Test

coefficients $^{\mathrm{a}}$

\begin{tabular}{cccccc}
\hline \multirow{2}{*}{ Model } & \multicolumn{2}{c}{ Unstandardized coefficient } & Standardized coefficient & \multirow{2}{*}{ t } & Sig \\
\cline { 2 - 4 } & $\mathrm{B}$ & Std. Error & Beta & & \\
\hline Constant & 0.87 & 0.549 & & 1.585 & 0.119 \\
\hline Profitabilitas & -1452 & 0.161 & -0.832 & -9031 & 0 \\
\hline Struktur Aset & -0.386 & 0.125 & -0.292 & -3087 & 0.003 \\
\hline Growth & 0.155 & 0.065 & 0.21 & 2.391 & 0.021 \\
\hline Size & 0 & 0.017 & 0.002 & 0.018 & 0.986 \\
\hline
\end{tabular}

a. Dependent Variabel : struktur model

1. Uji $t$ Test Parsial: Variabel Profitabilitas terhadap Variabel Struktur Modal

Berdasarkan output Coefficients di atas, diketahui bahwa nilai koefisien variabel profotabilitas sebesar -1.45 bernilai negatif sehingga dapat dikatakan bahwa variabel profitabilitas berpengaruh negatif terhadap struktur modal. Sedangkan untuk signifikansi diketahui nilai Sig. $0<0,05$ sehingga dapat dikatakan variabel bebas (profitabilitas) berpengaruh signifikan terhadap variabel terikat (struktur modal).

Berdasarkan hasil analisis regresi diketahui nilai t hitung $9.031>$ t tabel 2,01 dan nilai Sig. $0.0<0,05$ yang berarti profitabilitas berpengaruh signifikan terhadap struktur modal.

2. Uji t Test Parsial: Variabel Struktur Aset terhadap Variabel Struktur Modal Berdasarkan output koefisien di atas, diketahui bahwa nilai koefisien variabel struktur aset sebesar -0.38 bernilai negatif sehingga dapat dikatakan bahwa variabel struktur aset berpengaruh negatif terhadap struktur modal.
Sedangkan untuk signifikansi diketahui nilai Sig. $0,003<0,05$ sehingga dapat dikatakan variabel bebas (struktur aset) berpengaruh signifikan terhadap variabel terikat (struktur modal).

Berdasarkan hasil analisis regresi diketahui nilai t hitung $3.087>$ $\mathrm{t}$ tabel 2,01 dan nilai Sig. 0,003 $<0,05$ yang berarti struktur aset berpengaruh signifikan terhadap struktur modal.

3. Uji $t$ Test Parsial: Variabel Pertumbuhan Perusahaan (Growth) terhadap Variabel Struktur Modal

Berdasarkan output Coefficients di atas, diketahui bahwa nilai koefisien variabel pertumbuhan perusahaan sebesar 0.15 bernilai positif sehingga dapat dikatakan bahwa variabel pertumbuhan perusahaan berpengaruh positif terhadap struktur modal.

Sedangkan untuk signifikansi diketahui nilai Sig. $0,021<0,05$ sehingga dapat dikatakan variabel bebas (pertumbuhan perusahaan) berpengaruh signifikan terhadap variabel terikat (struktur modal).

Berdasarkan hasil analisis regresi diketahui nilai thitung $2.39>\mathrm{t}$ tabel 2,01 dan nilai signifikansi (Sig.) 
$0,021<0,05$ yang berarti pertumbuhan perusahaan berpengaruh signifikan terhadap struktur modal.

4. Uji t Test Parsial: Variabel Ukuran Perusahaan terhadap Variabel Struktur Modal

Berdasarkan output Coefficients di atas, diketahui bahwa nilai koefisien variabel ukuran perusahaan sebesar 0.000 bernilai positif sehingga dapat dikatakan bahwa variabel ukuran perusahaan berpengaruh positif terhadap struktur modal.

Sedangkan untuk signifikansi diketahui nilai Sig. $0,98>0,05$ sehingga dapat dikatakan variabel bebas (ukuran perusahaan) tidak berpengaruh signifikan terhadap variabel terikat (struktur modal).

Berdasarkan hasil analisis regresi diketahui nilai t hitung $0.018<$ $\mathrm{t}$ tabel 2,01 dan nilai signifikansi (Sig.) $0,98>0,05$ yang berarti ukuran perusahaan tidak berpengaruh signifikan terhadap struktur modal.

5. Uji F (Uji Annova)

Uji $F$ atau ANOVA (analysis of varians) digunakan untuk menguji pengaruh seluruh variabel independen yaitu profitabilitas, struktur aset, pertumbuhan perusahaan dan ukuran perusahaan secara bersama-sama terhadap variabel tetap yaitu struktur modal.

Tabel 7

Anova $^{\text {a }}$

\begin{tabular}{cccccc}
\hline Model & Sum of square & df & Mean of square & F & Sig \\
\hline Registrasion & 1.053 & 4 & 0.263 & 21.018 & $.000^{\mathrm{b}}$ \\
\hline Residual & 0.601 & 48 & 0.013 & & \\
\hline Total & 1.654 & 52 \\
\hline \multicolumn{7}{c}{ a. Dependent variable : struktur modal }
\end{tabular}

b. Predictors : (constant) size, growth, profitabilitas, struktur asset

Dari tabel hasil uji $f$ anova diperoleh nilai f 21,01 > f tabel 2,57 berarti dapat disimpulkan terdapat pengaruh simultan variabel bebas terhadap struktur modal.

Untuk signifikansi, nilai Sig. diperoleh $0<$ dari derajat signifikan yang ditetapkan 0,05 sehingga dapat disimpulkan bahwa pengaruhnya signifikan antara variabel bebas terhadap variabel terikatnya.

6. Analisis Determinasi (Adjusted R Square)

Analisis regresi berganda digunakan untuk melihat pengaruh dua variabel bebas atau lebih terhadap variabel terikat yang ada. Adapun persamaan analisis regresi berganda sebagai berikut :

$\mathrm{Y}=\mathrm{a}+\mathrm{b} 1 \mathrm{X} 1+\mathrm{b} 2 \mathrm{X} 2+\ldots \mathrm{bnXn}$

Keterangan:

$\mathrm{Y}=$ Variabel terikat (nilai yang diprediksikan)

$\mathrm{X} 1$ dan $\mathrm{X} 2=$ Variabel bebas

$\mathrm{a}=$ Konstanta (nilai $\mathrm{Y}^{\prime}$ apabila $\mathrm{X} 1$, $\mathrm{X} 2 \ldots . . \mathrm{Xn}=0$ )

$\mathrm{b}=$ Koefisien regresi (nilai peningkatan ataupun penurunan)

Analisis determinasi dalam regresi linear berganda digunakan untuk mengetahui prosentase sumbangan pengaruh variabel bebas (profitabilitas, struktur aset, pertumbuhan perusahaan dan ukuran perusahaan) secara serentak terhadap variabel terikat (struktur modal). 
Koefisien ini menunjukkan seberapa besar prosentase variasi variabel bebas yang digunakan dalam model mampu menjelaskan variasi variabel terikat.

Jika R2 sama dengan 0, maka tidak ada sedikitpun prosentase sumbangan pengaruh yang diberikan variabel bebas terhadap variabel terikat, atau variasi variabel bebas yang digunakan dalam model tidak menjelaskan sedikitpun variasi variabel terikat. Sebaliknya jika R2 sama dengan 1, maka prosentase sumbangan pengaruh yang diberikan variabel bebas terhadap variabel terikat adalah sempurna, atau variasi variabel bebas yang digunakan dalam model menjelaskan $100 \%$ variasi variabel terikat.

Berdasarkan hasil analisis regresi diketahui pada output model summary disajikan tabel diatas diperoleh angka $\mathrm{R}$ square sebesar 0,637 atau $63,7 \%$ yang berarti bahwa prosentase sumbangan pengaruh variabel bebas (profitabilitas, struktur aset, pertumbuhan perusahaan dan ukuran perusahaan) terhadap variabel terikat (struktur modal) sebesar $63,7 \%$. Atau dengan kata lain variasi variabel bebas mampu menjelaskan sebesar $63,7 \%$ atas variasi variabel terikat (struktur modal) sedangkan sisanya sebesar 36,3\% dipengaruhi atau dijelaskan oleh variabel lain yang tidak dimasukkan dalam penelitian ini.

Menurut (Santoso, 2013) bahwa untuk regresi dengan lebih dari dua variabel bebas digunakan adjusted R2 sebagai koefisien determinasi. Dari tabel di atas adjusted R2 sebesar 0,606 atau $60,6 \%$ yang berarti prosentase variabel bebas mempunyai pengaruh kepada variabel terikat sebesar $60,6 \%$. Berdasarkan Sugiyono, interpretasi dari nilai $60,6 \%$ berarti pengaruh variabel bebas kuat terhadap variabel terikatnya.

Dalam penelitian ini standard error of estimate 0,11 lebih kecil dari standar deviation struktur modal 0,17 yang berarti model regresi ini baik dalam memprediksi nilai $Y$.

\section{B. Pembahasan}

1. Pengaruh probabilitas terhadap struktur modal

Dari hasil pengujian yang dilakukan terbukti bahwa variabel profitabilitas berpengaruh signifikan terhadap struktur modal. Hal ini didukung hasil pengujian profitabilitas secara parsial pada uji t-parsial 9,03 jauh di atas angka $\mathrm{t}$ tabel 2,01 dan signifikan $0<0,05$.

Hal ini sejalan dengan pernyataan bahwa perusahaan dengan keuntungan yang besar cenderung akan menggunakan proporsi hutang yang relatif kecil karena dengan keuntungan yang tinggi kebutuhan dana diperoleh dari laba ditahan dan penelitian yang menyatakan bahwa perusahaan dengan keuntungan yang besar akan mengatur pinjamannya menjadi lebih rendah daripada sebelumnya.

Penelitian ini memperkuat hasil penelitian (Wijaya \& Utama, 2014) yang menyatakan bahwa profitabilitas berpengaruh terhadap struktur modal dan harga saham. Penelitian (Daulay, 2009) yang menyatakan bahwa profitabiltas berpengaruh positif dan signifikan terhadap struktur modal.

2. Pengaruh struktur aset terhadap struktur modal

Dari hasil pengujian t-test parsial terbukti bahwa variabel struktur aset berpengaruh signifikan terhadap struktur modal perusahaan. Hal ini dilihat dari nilai t hitung 3.087 
$>$ t tabel 2,010 dan nilai Sig. $0,003<$ 0,05 .

Hal ini sejalan dengan pernyataan bahwa perusahaan dengan jumlah aktiva tetap yang lebih besar dapat memperoleh dana yang lebih besar pula dari pinjaman hutang karena aktiva tetap tersebut dapat digunakan sebagai jaminan serta penelitian lain yang menyimpulkan bahwa aset tetap juga dapat dijadikan jaminan oleh perusahaan karena adanya pendanaan melalui hutangnya (Titman \& Wessels, 1988).

Penelitian ini memperkuat hasil penelitian I Putu Andre Sucita Wijaya et al., 2014 yang menyatakan bahwa struktur aset berpengaruh terhadap struktur modal.

3. Pengaruh pertumbuhan perusahaan terhadap struktur modal

Pengujian $t$ test parsial ditemukan nilai thitung $2.391>\mathrm{t}$ tabel 2,01 dan nilai Sig. $0,021<0,05$ yang berarti pertumbuhan perusahaan berpengaruh signifikan terhadap struktur modal.

Hasil ini juga sejalan dengan dengan beberapa penelitian Ida Bagus (Kartika, 2016) dan (Daulay, 2009) penelitian yang menyimpulkan bahwa terdapat pengaruh positif dan signifikan pertumbuhan perusahaan terhadap struktur modal.

4. Pengaruh ukuran perusahaan terhadap struktur modal

Dengan hasil pengujian nilai $\mathrm{t}$ hitung $0.018<\mathrm{t}$ tabel 2,01dan nilai signifikansi 0,986 > 0,05 yang berarti ukuran perusahaan terbukti tidak berpengaruh dan tidak signifikan terhadap struktur modal.

Hasil penelitian ini menguatkan pernyataan sebelumnya bahwa tidak adanya pengaruh antara ukuran yang dimiliki oleh suatu perusahaan dengan besarnya hutang yang dilakukan oleh perusahaan (Marsh, 1982; Titman and Wessels, 1988) dalam (Ooi, 1999).

Tidak adanya pengaruh ukuran perusahaan terhadap struktur modal ini disebabkan oleh keputusan investasi/pendanaan perusahaan lebih dipengaruhi faktor lain.

5. Pengaruh Variabel Bebas Secara Simultan terhadap Variabel Terikat

Secara simultan berdasarkan pengujian anova terhadap struktur modal diperoleh hasil nilai $\mathrm{f} 21,018>\mathrm{f}$ tabel 2,57 yang berarti bahwa terdapat pengaruh simultan antara empat variabel bebas (profitabilitas, struktur aset, pertumbuhan perusahaan dan ukuran perusahaan) terhadap struktur modal. Pengaruh ini bersifat signifikan terbukti dari derajat signifikansi dengan nilai Sig. diperoleh $0<$ dari derajat signifikan yang ditetapkan 0,05 .

Berdasarkan pengujian melalui adjusted R2 dibuktikan bahwa signifikansi tersebut berada pada angka $60,6 \%$ dipengaruhi oleh keempat (Sugiyono, 2017) angka $60,6 \%$ ini memberikan interpretasi koefisien korelasi pengaruh keempat variabel bebas terhadap variabel terikat berada pada tingkat pengaruh yang kuat dan selebihnya disebabkan faktor lainnya senilai $39,4 \%$. Hal ini diperkuat dengan hasil penelitian yang menunjukkan nilai standard error of the estimate < standar deviasi variabel terikat yaitu $0,111<0,177$ membuktikan bahwa model regresi ini baik dalam memprediksi variabel terikat. Disamping itu dapat dijelaskan
bahwa perusahaan dengan
profitabilitas yang tinggi, memiliki
pertumbuhan yang tinggi dan memiliki 
aset cukup besar mempengaruhi struktur modal perusahaan tersebut.

\section{Kesimpulan}

Penelitian mendukung hipotesis pertama yang menyatakan bahwa struktur aktiva berpengaruh terhadap struktur modal pada perusahaan automotive yang terdaftar di Bursa Efek Indonesia periode 2008-2011.

Penelitian mendukung hipotesis kedua yang menyatakan bahwa pertumbuhan aktiva berpengaruh terhadap struktur modal pada perusahaan automoti yang terdaftar di Bursa Efek Indonesia periode 2008-2011.

Penelitian mendukung hipotesis ketiga yang menyatakan bahwa profitabilitas berpengaruh terhadap struktur modal pada perusahaan automotive yang terdaftar di Bursa Efek Indonesia periode 2008-2011..

Pengujian secara parsial masingmasing variabel bebas dibuktikan bahwa tiga variabel bebas yaitu profitabilitas, struktur aset dan pertumbuhan perusahaan memiliki pengaruh positif dan signifikan terhadap variabel struktur modal.

Secara simultan keempat variabel bebas tersebut memiliki pengaruh yang simultan dan signifikan terhadap struktur modal. Pengaruh tersebut berada pada tingkat pengaruh yang kuat pada angka $60,6 \%$ mempengaruhi struktur modal.

Keterbatasan penelitian dalam penelitian ini antara lain yaitu hanya satu rasio yang dipakai untuk masing-masing variabel. Sebagai contoh variabel profitabilitas yang dapat diukur dengan beberapa rasio seperti basic earning power ratio dan return on equity ratio tidak dipakai. Jumlah sampel yang digunakan hanya 11 perusahaan industri kelapa sawit tanpa mengikutkan industri turunannya seperti industri pengolahan lanjutan CPO menjadi minyak goreng.

\section{BIBLIOGRAFI}

Ang, R. (1997). Buku pintar pasar modal Indonesia. Jakarta: Mediasoft Indonesia.Google Scholar

Brigham, E. F., \& Houston, J. F. (2006). Fundamentals of Financial Management: Dasar-Dasar Manajemen Keuangan. Google Scholar

Brigham, E. F., \& Houston, J. F. (2010). Dasar-Dasar Manajemen Keuangan: Essensial of Financial Management Buku 1. Google Scholar

Cahyono, D. (2017). Pengaruh Harga Dan Kualitas Jasa Terhadap Keputusan Pembelian Ulang Telkom Malang (Studi Pada Pelanggan Telkom Indihome Cabang Malang). University of Muhammadiyah Malang. Google Scholar

Daulay, M. T. (2009). Pengaruh Size, Profitability dan Growth of Assets terhadap Struktur Modal Pada Industri Makanan dan Minuman yang Go Public di Bursa Efek Indonesia. Jurnal Ilmiah Abdi Ilmu, 2(2). Google Scholar

Febrioni, R., Isynuwardhana, D., \& Nazar, M. R. (2016). Pengaruh Return On Assets, Return On Equity, Earning Per Share, Dan Current Ratio Terhadap Return Saham (pada Perusahaan Yang Terdaftar Pada Indeks Lq45 Di Bursa Efek Indonesia Tahun 2011-2015. EProceedings of Management, 3(3). Google Scholar

Husnan, S. (2004). Enny Pudjiastuti. 2004. Dasar-Dasar Manajemen Keuangan. Google Scholar

Janie, D. N. A. (2012). Statistik deskriptif \& regresi linier berganda dengan SPSS. Jurnal, April. Google Scholar

Kartika, A. (2016). Pengaruh profitabilitas, struktur aset, pertumbuhan penjualan dan ukuran perusahaan terhadap struktur modal perusahaan manufaktur di Bursa 
Efek Indonesia. Infokam, 12(1). Google Scholar

Ooi, J. (1999). The determinants of capital structure evidence on UK property companies. Journal of Property Investment \& Finance. Google Scholar

Pahan, I. (2008). Paduan Lengkap Kelapa Sawit. Niaga Swadaya. Google Scholar

Pahan, I. (2012). Panduan Teknis Budidaya Kelapa Sawit. Penebar Swadaya Grup. Google Scholar

Rini, A. C. (2014). Studi Empiris FaktorFaktor Yang Mempengaruhi Struktur Modal Pada Perusahaan Manufaktur Di Bursa Efek Indonesia Periode Tahun 2011-2013. Google Scholar

Santoso, C. E. E. (2013). Perputaran modal kerja dan perputaran piutang pengaruhnya terhadap profitabilitas pada PT. Pegadaian (PERSERO). Jurnal EMBA: Jurnal Riset Ekonomi, Manajemen, Bisnis Dan Akuntansi, 1(4). Google Scholar
Sugiyono. (2017). Metode Penelitian Kuantitatif. Google Scholar

Tbk, P. P. T. I. T. M., \& Tbk, P. T. B. A. (2013). Analisis Kebangkrutan Perusahaan Dalam Hubungannya dengan Kebijakan Struktur Modal dan Biaya Modal. Google Scholar

Titman, S., \& Wessels, R. (1988). The determinants of capital structure choice. The Journal of Finance, 43(1), 1-19. Google Scholar

Weston, J. F., \& Brigham, E. F. (2001). Dasar-dasar Manajemen Keuangan, edisi 9. Penerbit Erlangga. Jakarta. Google Scholar

Wijaya, I., \& Utama, I. M. K. (2014). Pengaruh profitabilitas, struktur aset, dan pertumbuhan penjualan terhadap struktur modal serta harga saham. EJurnal Akuntansi Universitas Udayana, 6(3), 514-530. Google Scholar

\section{Copyright holder :}

Carissa Dessy Rianti, Marsheila Eka Dianti, Sandra Zaeni (2022)

First publication right :

Jurnal Syntax Transformation

This article is licensed under: 